\title{
Tipologi batas wilayah administrasi untuk memudahkan pengelolaan batas daerah di Indonesia
}

\author{
Fahrul Hidayat ${ }^{*}$ Munawaroh dan Tia Rizka Nuzula Rachma
}

Badan Informasi Geospasial

Direvisi: 2021-01-24 Diterima: 2021-03-12

(C)2021 Fakultas Geografi UGM dan Ikatan Geograf Indonesia (IGI)

\begin{abstract}
Abstrak Terhitung sejak 1945 - 2017, baru sekitar 48\% dari 977 segmen batas daerah di Indonesia yang disahkan melalui Peraturan Menteri Dalam Negeri tentang batas daerah. Pengelolaan batas wilayah daerah sangat penting untuk berbagai urusan pembangunan misalnya pengelolaan sumber daya alam. Oleh karena itu, penelitian ini mengusulkan pendekatan baru untuk mendukung pengelolaan batas wilayah yang efisien yaitu melalui segmentasi berbasis tipologi batas wilayah. Tahapan analisis meliputi: membandingkan, memotong, dan mengelompokkan garis batas. Single Buffer Overlay Method digunakan untuk membandingkan unsur geografis pada Peta Rupabumi Indonesia (data referensi) dan garis batas 2017 (data yang diuji). Selanjutnya, dilakukan pemotongan garis sesuai hasil perbandingan. Pada akhirnya, garis tersebut dikelaskan berdasarkan tipologinya (igir, jalan, dan sungai) menggunakan metode SQL (Structured Query Language). Hasil penelitian menunjukkan bahwa mayoritas $(41,8 \%)$ batas daerah di Indonesia tidak menggunakan unsur geografis tertentu sebagai penanda batasnya, sedangkan persentase penanda batas berupa sungai $35,9 \%$, igir $16,4 \%$, dan jalan $5,8 \%$.
\end{abstract}

Kata kunci: batas daerah, segmentasi, unsur geografis

\begin{abstract}
Since 1945 - 2017, only 48\% of 977 regional borderlines of Indonesia were legalized by The Ministry of Home Affairs. Properly managed intra-national boundaries are fundamental for development purposes e.g. natural resource management. Therefore, this research proposed a new approach to help managing the boundary efficiently through typology-based borderlines segmentation which was conducted by some stages: compare, split, and classify lines. Single Buffer Overlay Method used for comparison purpose by utilizing some geographical features on a topographic map as a referenced dataset and boundary line (2017 database) as a tested dataset. Then we split the lines based on the comparison result. Finally, each split line was classified into border typologies (road, ridge, and stream) by using the SQL (Structured Query Language) method. We found that most of The Indonesian administrative boundary segments (41.8\%) did not use a geographical feature, while the boundary on the rivers $35.9 \%$, ridges $16.4 \%$, and roads $5.8 \%$.
\end{abstract}

Keywords: intra-national boundaries, segmentation, geographical features

\section{PENDAHULUAN}

Pengelolaan batas teritorial dalam konteks wilayah internasional menurut (Blake, 1998) bertujuan untuk perdamaian internasional, keamanan nasional, kesejahteraan wilayah perbatasan, dan efektivitas pemerintahan lokal. Masih merujuk pada (Blake, 1998), pengeolaan batas wilayah dipengaruhi oleh beberapa kelompok faktor yaitu sejarah batas, status hukum, tipe/tipologi garis batas, geografi fisik (penutup lahan), geografi manusia (sosial dan budaya), dan akses (jalur lintas batas). Tipologi atau dikotomi jenis penanda batas wilayah sudah sejak lama dikemukakan oleh para pakar perbatasan. Menurut (Jones, 1945) batas wilayah secara umum dikelompokkan menjadi batas alami ("natural") dan batas buatan ("artificial") yang dapat berupa punggung bukit/gunung, sungai, geometri, dan lainnya. Kemudian, (Blake, 1998) memperjelas lagi klasifikasi tersebut ke dalam 3 (tiga) tipe garis batas wilayah, yaitu: 1) unsur fisik (physiographic boundaries) misalnya sungai, igir, danau; 2) unsur buatan manusia (anthropomorphic boundaries) misalnya jalan, rel kereta, rute karavan di gurun; dan 3) garis lurus (geometric boundaries) baik berdasarkan garis lintang atau bujur maupun garis yang menghubungkan 2 (dua) titik koordinat tertentu.

Pada konteks batas intra-nasional, penelitian yang di lakukan oleh (Sumaryo, 2015) menunjukkan bahwa teori "boundary making" yang dikemukakan oleh (Jones, 1945) masih relevan untuk batas daerah. Tahapan "boundary making" pada dasarnya terdiri dari alokasi, delimitasi, dan demarkasi batas, namun terus berkembang termasuk diantaranya (Srebro \& Shoshany, 2013) yang mengusulkan 2 (dua) tahapan tambahan yaitu dokumentasi batas dan pemeliharaan batas. Salah satu instrumen untuk implementasi teori tersebut dalam penyelenggaraan batas daerah di Indonesia adalah melalui Peraturan Menteri Dalam Negeri (Permendagri) tentang Penegasan Batas Daerah yang di dalamnya memuat tahapan umum yaitu penyiapan dokumen, pelacakan batas, pengukuran posisi batas, dan pembuatan peta batas. Permendagri yang saat ini berlaku adalah Permendagri Nomor 141 tahun 2017. Data batas wilayah tahun 2017 dari Kementerian Dalam Negeri (Kemendagri) menunjukkan bahwa sekitar 48\% dari total 
977 segmen batas telah disahkan dan memiliki Permendagri batas daerah. Setiap segmen yang telah ditetapkan melalui Permendagri tentang batas daerah memiliki 2 (dua) bagian utama yaitu: 1) batang tubuh yang berisi penjelasan segmen batas; dan 2) lampiran berupa peta batas wilayah beserta koordinat batasnya. Namun demikian, tidak semua Permendagri batas menjelaskan secara detail tentang penanda batas di dalam batang tubuhnya.

Pada era digital dan didukung kemampuan Sistem Informasi Geografis (SIG) saat ini, dokumentasi batas wilayah dapat dibuat selengkap mungkin untuk menyediakan informasi batas yang andal dan memudahkan pengelolaan batas (Adler, 2001). Sayangnya, hingga saat ini belum ada basis data atau pendokumentasian secara komprehensif tentang penanda batas seluruh wilayah Indonesia melainkan parsial dan hanya berupa narasi dalam dokumen Permendagri. Biasanya, pemerintah daerah memerlukan rincian penanda batas tersebut saat menghadapi sengketa batas. Penelitian ini berfokus pada salah satu faktor yang memengaruhi pengelolaan batas yang dikemukakan oleh (Blake, 1998) yaitu tipologi batas.

Menurut (Prescott, 1965), mayoritas studi yang dilakukan oleh geograf, ahli sejarah, dan ahli hukum berkonsentrasi pada studi batas internasional. Sementara kondisi tersebut berbeda dengan saat ini yang mana sudah banyak dilakukannya penelitian terhadap batas intra-nasional pada beberapa pokok bahasan tertentu di berbagai negara, diantaranya adalah: 1) rekonstruksi batas dengan tujuan untuk melacak ulang batas intra-nasional (Provinsi Valencia, Spanyol) menggunakan data lama/kuno dan survei lapangan (Femenia-Ribera, Benitez-Aguado, Mora-Navarro, \& Martinez-Llario, 2014); 2) konflik kartografis untuk wilayah Nagaland di India (Agrawal \& Kumar, 2017); 3) konfigurasi ulang administrative geographies di Amerika Serikat (Harvey, 2006); dan masih banyak yang lainnya. Penelitian terhadap batas intra-nasional di Indonesia juga telah banyak dilakukan baik pada konteks hukum maupun spasial dari batas daerah (kabupaten/kota), misalnya oleh akademisi (dosen dan mahasiswa) dan praktisi yaitu (Dumanauw, 2013; Kristiyono, 2008; La Suhu, Noor, \& Djae, 2018; Riadi \& Soleman, 2011; Rumesten, 2013; Sumaryo, Sutisna, Subaryono, \& Djurdjani, 2014). Selain batasantarkabupaten/ kota, penelitian tentang batas intra-nasional pada tingkat yang lebih rinci yaitu desa/kelurahan juga telah banyak dilakukan di Indonesia misalnya untuk evaluasi ketelitian, implementasi peraturan penegasan, komparasi metode, dan hasil pemetaan batas desa (Ahmad \& Zuharnen, 2017; Anggoro, 2018; Asadi, 2016; Astuty, Hidayat, \& Prihanggo, 2019; Bashit, Prasetyo, Firdaus, \& Amarrohman, 2019; Prakasa, 2017; Pratiwi, 2018; Putra \& Dewi, 2020; Riadi \& Makmuriyanto, 2014; Sardiana \& Windia, 2018; Sinaga, 2015; Sutanta, Pratiwi, Atunggal, Cahyono, \& Diyono, 2020; Talitha, 2015; Wibowo, Ambhika, \& Pratama, 2019; Zarodi, Rofi, Anshori, \& Widarto, 2019). Dari sekian banyak penelitian tentang batas intra-nasional, belum ada yang spesifik tentang tipologi batas daerah, baik di Indonesia maupun di negara lain. Penelitian tentang batas daerah di Indonesia lebih fokus pada solusi penyelesaian sengketa yang sifatnya kasus per kasus (segmen) tertentu dan hanya mengacu pada peraturan/pedoman penegasan batas daerah yang sudah ada misalnya oleh (Arifin, 2016; Khomsin, Widiastuty, Alif, \& Artanto, 2015). Masih jarang ditemukan penelitian tentang batas daerah dengan lingkup wilayah seluruh Indonesia seperti yang dilakukan oleh (Sumaryo, Subaryono, Sutisna, \& Wardaya, 2014) dan (Hidayat, Riadi, \& Turmudi, 2018).

Meskipun demikian, terdapat salah satu basis data batas internasional yang relevan dengan penelitian ini. Basis data tersebut dipublikasikan oleh International Boundary Research Unit (IBRU) dengan judul Specialized Maps and Databases khusus tentang International River Boundaries Database (IRBD). IRBD menyajikan data batas internasional yang menjadikan unsur geografis sungai sebagai penanda batasnya (Donaldson, 2009). Selain IRBD, terdapat global database lain yang menyajikan batas wilayah berupa sungai, yaitu Shared Rivers (SRDB) (Toset, Gleditsch, \& Hegre, 2000) dan Trans-boundary Water Management Database (Earle, 2010). Contoh diatas menjadi penting untuk digarisbawahi bahwa batas pada tipologi tertentu perlu diidentifikasi karena memiliki manfaat yang besar bagi pengelolaan suatu wilayah. Ketersediaan penanda batas pada skala global saat ini terbatas pada tipologi sungai.

Berpijak pada hal tersebut, penelitian ini bertujuan untuk mengusulkan sebuah pendekatan baru dalam mendukung pengelolaan batas administrasi melalui teknik segmentasi batas wilayah administrasi berdasarkan tipologi batasnya. Tipologi batas yang digunakan tidak hanya unsur geografis sungai, melainkan juga jalan, dan igir. Kebaruan yang ditawarkan dari penelitian ini adalah memberikan informasi spasial tentang komposisi penanda batas tiap segmen antarwilayah administrasi dalam satu negara sekaligus, sehingga dapat memudahkan pengelolaan batas wilayah administrasi. Dengan diketahuinya tipologi batas daerah, maka Tim Penegasan Batas Daerah (baik tingkat provinsi maupun pusat) dapat lebih cepat menentukan prioritas penyelesaian penegasan batas daerah. Begitu pula Tim Penegasan Batas daerah di tingkat kabupaten/kota yang dapat menentukan prioritas alokasi sumber daya (manusia dan anggaran) untuk mengelola batasnya. Batas berupa jalan yang berada di pusat permukiman memerlukan pilar yang lebih banyak dibanding batas berupa igir yang berada di hutan. Uraian diatas adalah contoh kemudahan pengelolaan yang dapat diperoleh dari hasil penelitian ini. Penelitian ini merupakan pengembangan dari penelitian sebelumnya yang dilakukan oleh penulis pada 2015. Penelitian tersebut hanya menggunakan batas yang telah memiliki dasar hukum berupa Permendagi batas wilayah atau sudah definitif pada daerah di Pulau Sumatera (Hidayat, Astuty, Suryanto, \& Saputro, 2015). Pada penelitian ini, studi kasus yang diambil adalah seluruh wilayah Indonesia dengan justifikasi keberagaman dan kompleksitas (dari tingkat desa/keluarahan sampai dengan provinsi) batas wilayah administrasinya. Hasil penelitian ini diharapkan dapat memberikan gambaran tentang pendekatan segmentasi batas wilayah intra-nasional pada negara berkembang dan dapat diadopsi oleh di negara lain yang memiliki sistem pembagian wilayah administrasi yang serupa.

\section{METODE PENELITIAN}

Batas wilayah dan unsur geografis

Segmen batas wilayah dijadikan sebagai data yang akan diuji (tested dataset) menggunakan data referensi (reference dataset). Penelitian ini dilakukan terhadap seluruh segmen batas daerah kabupaten/kota di Indonesia yang merupakan hasil integrasi dan sinkronisasi (Desember 2017) antara data BIG dengan Kemendagri (walidata batas daerah). Data 


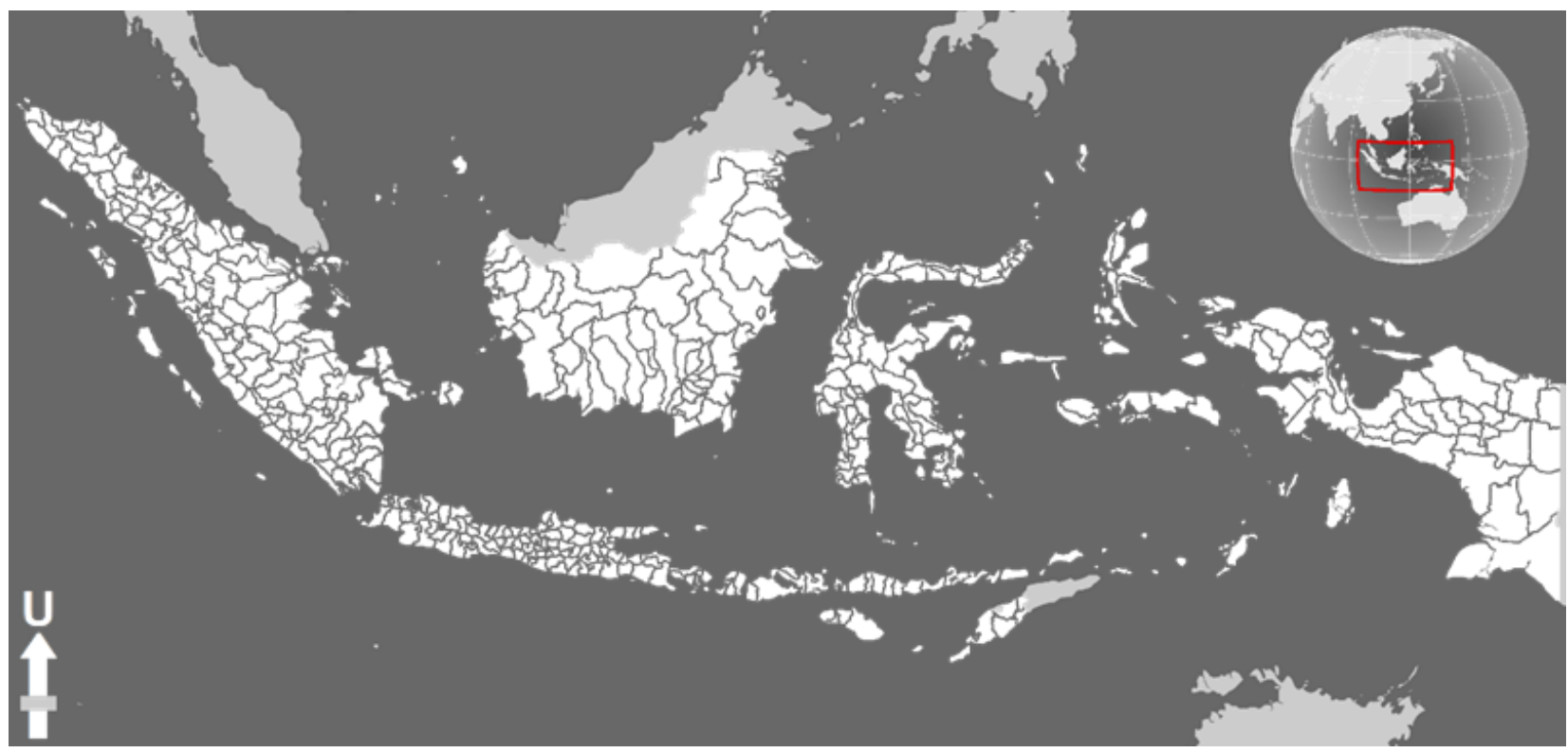

Gambar 1. Batas wilayah administrasi level 2 (kabupaten/kota) ditunjukkan dengan garis berwarna abu-abu tua. Pada level ini, batas kabupaten/kota pada provinsi tertentu bisa jadi berbatasan dengan provinsi lain

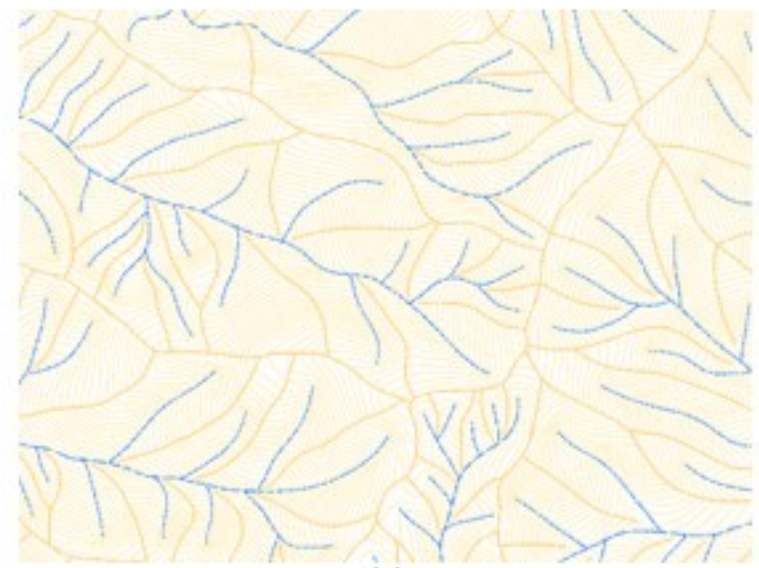

(a)

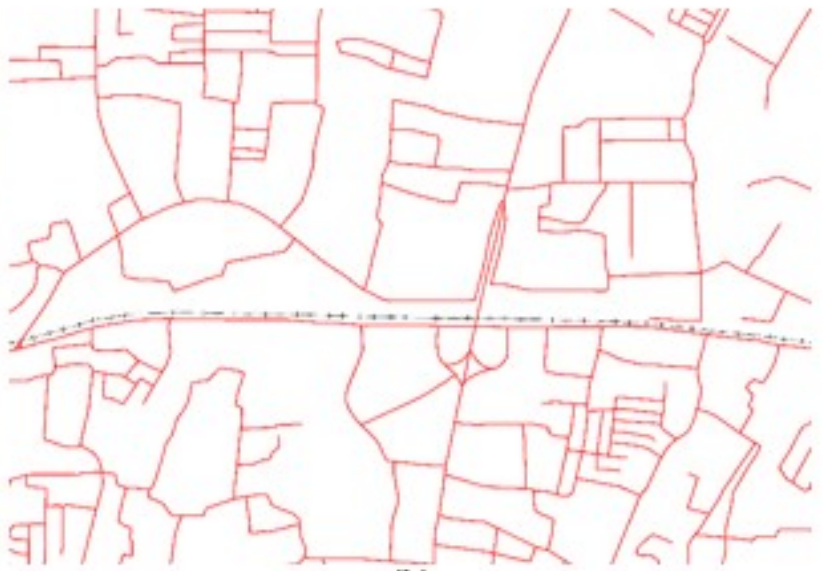

(b)

Gambar 2. Contoh unsur alami (a) berupa sungai (warna biru) \& igir (warna oranye) dan unsur buatan (b) berupa jalan (warna merah) dan \& rel kereta (warna hitam) yang ada pada Peta Rupabumi Indonesia format digital

(Sumber: https://tanahair.indonesia.go.id/portal-web)

tersebut diperoleh dari BIG khususnya Pusat Pemetaan Batas Wilayah (Gambar 1). Jumlah segmen batas sebanyak 977 segmen dalam bentuk digital (GIS ready) dengan ekstensi ESRI Shapefile. Sebanyak $48,31 \%$ dari total segmen sudah definitif atau disahkan dan ditetapkan dalam Permenadgri batas wilayah yang terus mengalami pertambahan jumlah setiap tahunnya. Pada tahun 2012 terjadi pertambahan jumlah segmen definitif yang signifikan sebagai konsekuensi diperbolehkannya metode kartometrik sebagai salah satu alternatif penegasan batas daerah yang diatur dalam Permendagri nomor 76 tahun 2012 (Hidayat et al., 2018).

Data referensi yang digunakan adalah unsur geografis yang diambil dari Peta Rupabumi Indonesia (RBI) format digital (ESRI Shapefile) bersumber dari Badan Informasi Geospasial. Skala data referensi yang tersedia adalah 1:50.000 untuk wilayah Sumatera, Kalimantan, Sulawesi, Maluku, dan Papua, sedangkan untuk wilayah Jawa, Bali, dan Nusa Tenggara tersedia pada skala 1:25.000. Perbedaan skala tersebut memengaruhi kedetailan geometri, sehingga untuk proses analisis yang berkaitan dengan ketelitian geometri akan mengacu nilai ketelitian pada skala yang lebih kecil yaitu 1:50.000. Tipe data digital unsur geografis tersebut adalah polyline atau garis, begitu pula dengan tipe data batas wilayah administrasi kabupaten/kota (data yang akan diuji penanda batasnya). Unsur geografis yang dipilih akan digunakan sebagai dasar penentuan kelas tipologi batas. Tipologi batas wilayah tersebut adalah: 1) batas yang mengikuti unsur alami (sungai, garis punggung bukit/igir), 2) batas yang mengikuti unsur buatan manusia (jalan/rel kereta); dan 3) batas yang tidak mengikuti unsur rupabumi atau berupa garis lurus yang mengubungkan dua titik koordinat atau mengikuti koordinat lintang/bujur (Gambar 2).

\section{Tahapan penelitian}

Penelitian dilakukan dengan tahapan seleksi, pemrosesan data, dan analisis (alur dapat dilihat pada Gambar 3). Tahapan seleksi data meliputi proses pemilihan unsur 
geografis penanda batas yang akan digunakan. Selanjutnya, tahapan pemrosesan data dilakukan untuk membandingkan garis batas wilayah administrasi kabupaten/kota dengan unsur geografis. Terdapat beberapa teknik komparasi garis dengan garis dalam bidang komputasi digital, misalnya relative sinousity dan longitudinal root mean squared error untuk mengevaluasi akurasi horizontal relatif pada suatu objek garis yang rumit atau kompleks sebagaimana dijelaskan oleh (Anderson, Ames, \& Yang, 2014). Selain itu, terdapat teknik lain yaitu dengan melakukan buffer terhadap salah satu objek garis yang dijadikan sebagai acuan (reference dataset). Teknik tersebut diperkenalkan oleh (Goodchild \& Hunter, 1997) untuk uji akurasi garis pantai menggunakan garis pantai lain yang memiliki akurasi lebih tinggi. Metode tersebut saat ini dikenal dengan istilah Single Buffer Overlay Method (SBOM). Sudah banyak digunakan oleh beberapa peneliti untuk keperluan uji akurasi obyek dengan tipe garis (Ariza-López, Ruiz-Lendínez, \& Ureña-Cámara, 2018; Ruiz-lendínez, 2020; Ruiz-Lendínez, Ariza-López, \& Ureña-Cámara, 2013). Metode yang digunakan dalam penelitian ini adalah teknik overlay garis berbasis buffer yang mengadopsi sebagian dari SBOM. Teknik buffer tersebut juga digunakan juga oleh Popleka (2020) untuk menghasilkan Global Subnational River-Borders Dataset (GSRB). GSRB adalah basis data yang berisi batas wilayah yang menggunakan sungai sebagai penanda batasnya. GSRB diklaim paling baik dibandingkan basis data serupa lainnya karena memiliki kedetailan hingga subnasional dan tersedia dalam format geospasial (Popelka \& Smith, 2020).

Tahapan penentuan tipologi batas wilayah di Indonesia dalam penelitian ini dimulai dari pemilihan unsur geografis dari peta RBI yang digunakan sebagai penanda batas wilayah. Pemilihan unsur tersebut memanfaatkan Structured Query Language (SQL). Unsur geografis tersebut yaitu jalan, sungai dan igir. Pemilihan tersebut berdasarkan justifikasi penanda batas yang umum digunakan yaitu jalan, sungai, dan igir/ garis punggung bukit dan sesuai ketentuan umum yang tercantum dalam Permendagri Nomor 141 tahun 2017 tentang Penegasan Batas Daerah. Usur geografis yang telah dipilih, kemudian dilakukan proses buffering dengan radius 25 meter. Penentuan radius buffer mengikuti nilai ketelitian horizontal peta RBI untuk kelas 3 skala 1:50.000 yang diatur dalam Peraturan Kepala Badan Informasi Geospasial nomor 15 tahun 2014 (Badan Informasi Geospasial, 2014) karena penelitian ini dilaksanakan pada 2018 dan menggunakan data yang dipublikasi pada 2017. Ketelitian horizontal dijadikan sebagai kriteria subsegmentasi karena kemungkinan kesalahan posisi garis batas diasumsikan berada pada radius (toleransi) kesalahan posisi penanda batas yaitu unsur rupabumi. Suatu subsegmen batas dapat dikatakan mengikuti penanda batas tertentu apabila garis batasnya berada di dalam poligon hasil buffer dan mengikuti pola suatu unsur geografis tertentu (Gambar 4a). Segmentasi batas kemudian dilakukan untuk mengelaskan tipologi batas wilayah administrasi yang mengikuti unsur RBI dan tidak mengikuti unsur RBI. Gambar $4 \mathrm{~b}$ menunjukkan proses pemotongan segmen batas menjadi beberapa subsegmen sesuai dengan unsur geografis penanda batasnya. Subsegmen hasil pemotongan dikelaskan melalui pengisian atribut tipologi batasnya. Selanjutnya, evaluasi dilakukan terhadap setiap segmen (dari awal sampai akhir batasantarkabupaten/ kota) untuk mengetahui kesalahan dalam proses segmentasi. Evaluasi ini masih dilakukan secara manual untuk mengatasi kendala ketidakteraturan geometri batas wilayah dan unsur rupabuminya.

Gambar 5 menunjukkan lokasi-lokasi yang berpotensi mengalami kesalahan dalam segmentasi. Lingkaran bergaris putus-putus memberikan penekanan bahwa meskipun garis batas yang berada di dalam poligon hasil buffer unsur rupabumi, garis batas tersebut tidak otomatis dapat

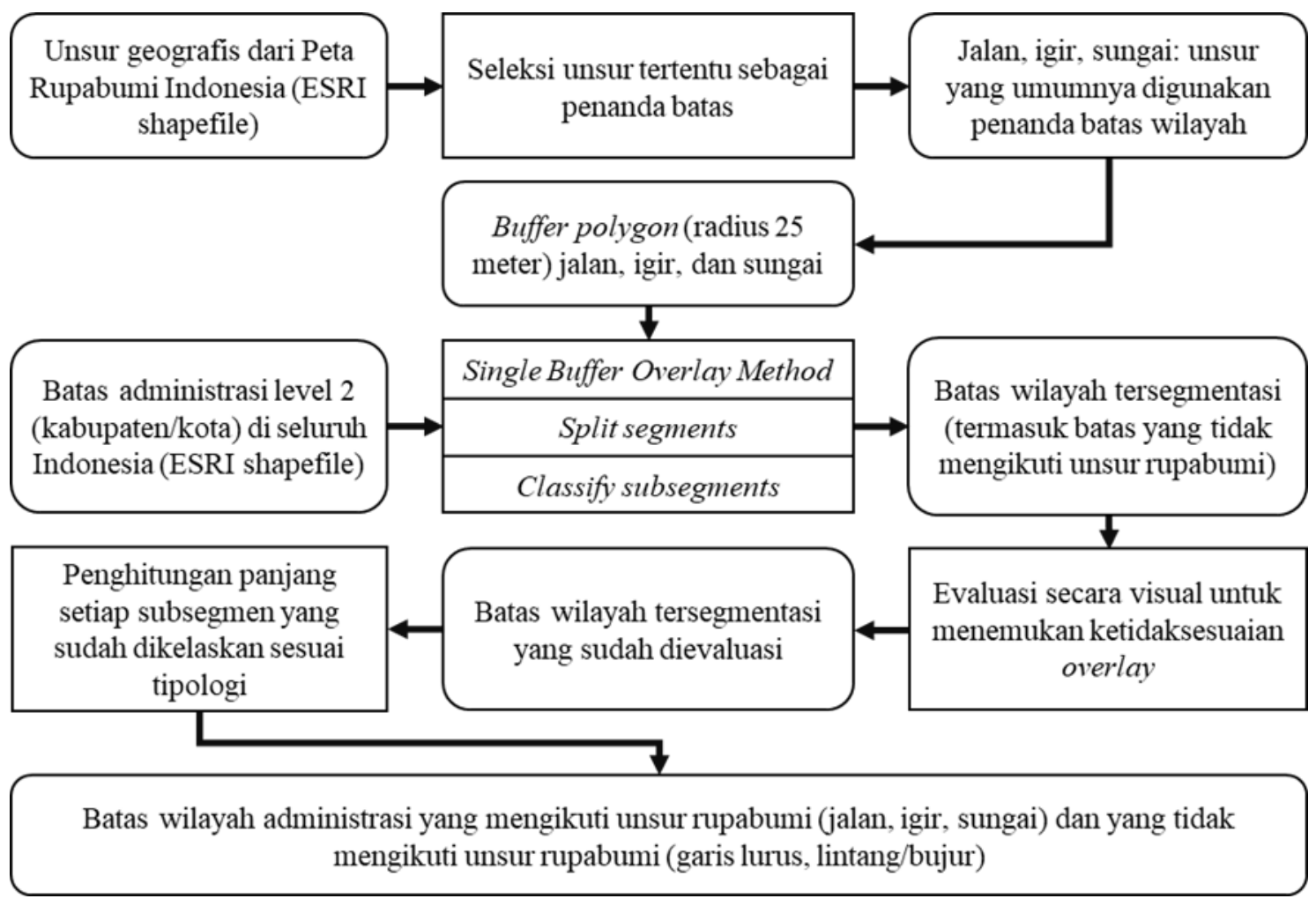

Gambar 3. Alur penelitian 


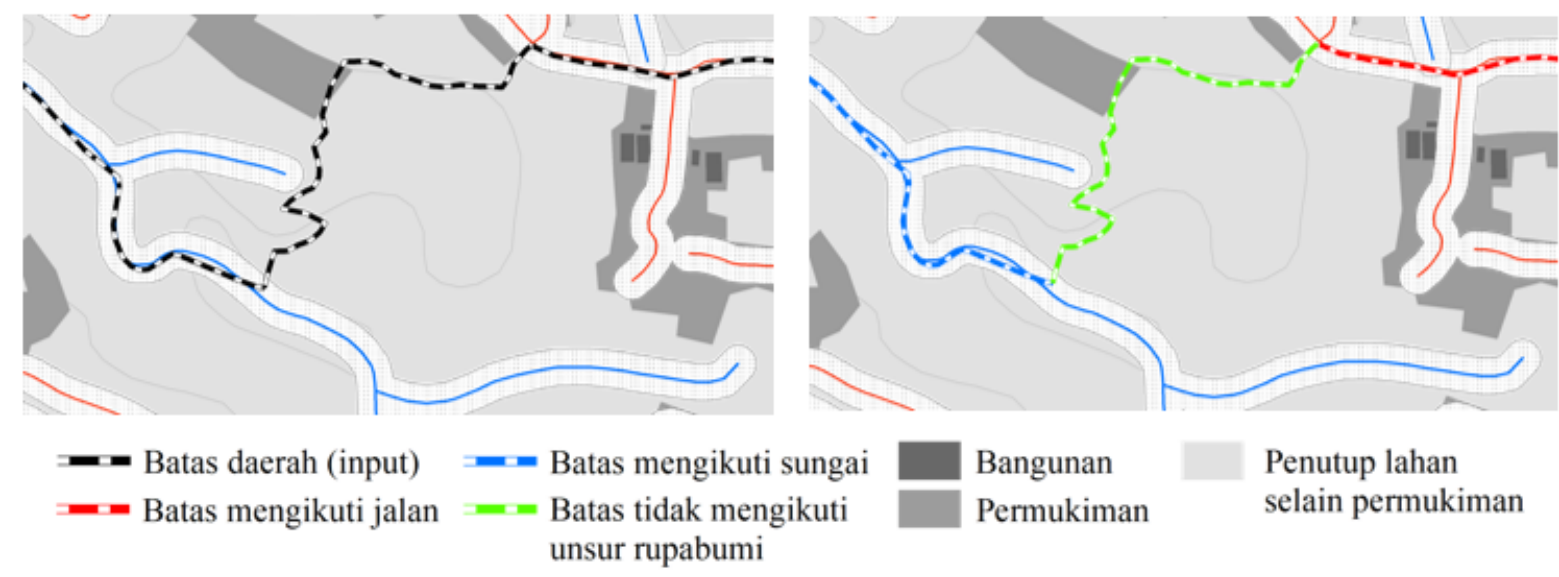

(a)

(b)

Gambar 4. Garis batas daerah (input) dibandingkan dengan poligon hasil buffer radius 25 meter (area yang diarsir) dari unsur rupabumi (a), kemudian membagi (split) dan mengelaskan (classify) sesuai tipologinya (b)

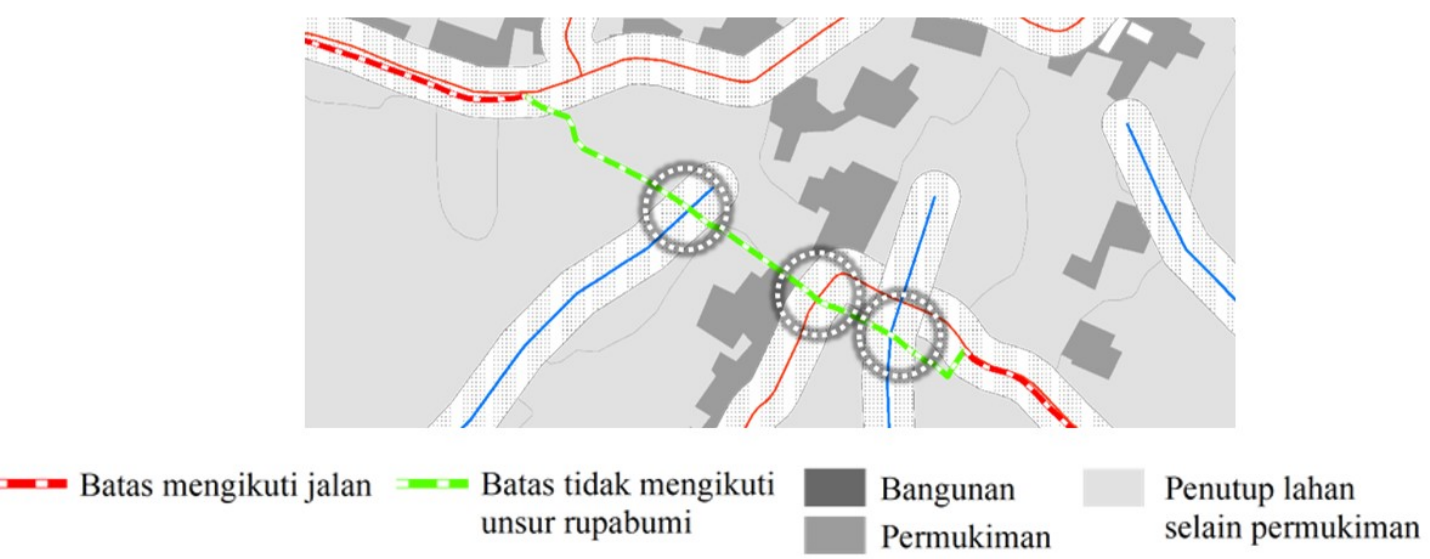

Gambar 5. Subsegmen yang berpotensi mengalami kesalahan saat proses segmentasi ditunjukkan dengan lingkaran bergaris putus-putus

dikategorikan sebagai batas yang mengikuti unsur rupabumi. Hal itu karena tidak memenuhi kirteria "mengikuti pola unsur rupabumi". Subsegmen seperti contoh tersebut kemudian dikategorikan sebagai batas yang tidak mengikuti unsur rupabumi. Setelah semua segmen dievaluasi, tahapan berikutnya adalah penghitungan panjang setiap subsegmen agar dapat diketahui komposisi dan proporsi setiap penanda batas daerah di Indonesia. Sistem proyeksi yang digunakan dalam penghitungan panjang adalah Mercator. Mercator merupakan sistem proyeksi yang merepresentasikan bumi sebagai bola dengan garis khatulistiwa/ekuator sebagai kurva singgung pada permukaan silinder (Prihandito, 2014) (Vallo, Valovicova, \& Kramarekova, 2019). Karena lokasi penelitian berada di sekitar ekuator, maka distorsi tidak akan terlalu besar (distorsi minimal) bila menggunakan Mercator (ESRI, 2019). Jika mengacu pada ketentuan yang tercantum dalam Permendagri Nomor 141 tahun 2017, maka Sistem proyeksi yang digunakan untuk pembuatan peta batas daerah adalah Mercator.

\section{HASIL DAN PEMBAHASAN}

Salah satu keunikan layer batas administrasi adalah pada proses penarikan garisnya. Banyak tahap yang harus dilalui, misalnya penyiapan dokumen (melibatkan aspek hukum dan sejarah), pemasangan pilar batas sebagai penanda pasti di lapangan, dan pembuatan peta. Kunci pemetaan batas ada pada kesepakatan antarpihak yang berbatasan. Kesepakatan menjadi tujuan utama penentuan batas dan memungkinkan terdapat kompromi dalam penentuan penanda batasnya. Menurut (Caflisch, 2010), tidak ada hukum tertentu yang menyatakan bahwa batas buatan (artificial) lebih baik daripada batas alam (natural) atau sebaliknya. Namun demikian, ada beberapa hal yang dapat mengubah batas yang sudah disepakati tersebut misalnya perang (konflik) (Srebro \& Shoshany, 2013), bencana alam, dan hasil keputusan pengadilan. Sebaliknya, kesepakatan yang belum tercapai selama proses penegasan batas daerah bisa dikatakan sebagai bagian dari permasalahan atau sengketa batas. Terdapat banyak faktor yang menyebabkan sengketa batas. Penelitian yang dilakukan oleh (Sumaryo, Subaryono, \& Sutisna, 2014) menunjukkan bahwa dari 25 sengketa batas yang terjadi antara kabupaten/kota di Indonesia, sebanyak 64\% disebabkan oleh data atau informasi geospasial (perbedaan interpretasi, data atau informasi tidak lengkap, dan lainnya), $20 \%$ karena kombinasi antara permasalahan informasi geospasial \& berkaitan dengan kepentingan (misalnya terkait sumber daya alam), dan $16 \%$ karena kombinasi antara 
permasalahan informasi geospasial, struktural (misalnya rendahnya kemauan pimpinan) \& kepentingan. Setiap kasus sengketa memiliki ciri khas masing-masing karena berhubungan dengan sosial \& budaya masyarakat lokal sebagai pihak yang paling dekat dengan wilayah perbatasan. Oleh karena itu, jangka waktu penyelesaian sengketa batas pun tidak bisa disamakan. Garis batas bisa jadi berubah (sebelum dan sesudah) diselesaikannya suatu sengketa. Perubahan tersebut berimplikasi pada perbedaan komposisi penanda batasnya dalam suatu segmen batas daerah.

Visualisasi hasil penelitian ini menerapkan pembagian region agar memudahkan pembaca dalam memahami konteks perbandingannya. Region tersebut terdiri atas: 1) Bali dan Nusa Tenggara; 2) Jawa; 3) Kalimantan; 4) Maluku dan Papua; 5) Sulawesi; dan 6) Sumatera. Setiap region meliputi pulau besar (sesuai nama region) dan pulau-pulau kecil yang ada di sekitarnya. Sesuai hasil penghitungan, panjang total 977 segmen batas adalah 67.456 kilometer dan region Sumatera memiliki total segmen terpanjang yaitu mencapai $32 \%$ dari seluruh segmen batas daerah di Indonesia. Jika dilihat berdasarkan kumulatif secara nasional, batas daerah yang tidak mengikuti unsur rupabumi memiliki proporsi terbesar, yaitu mencapai $41,8 \%$ dari total seluruh segmen, dilanjutkan batas yang mengikuti sungai (35,9\%), mengikuti igir (16,4\%), dan mengikuti jalan (5,8\%). Gambar 6 menunjukkan tipologi setiap segmen batas daerah berdasarkan persebaran secara spasial dan Gambar 7 menunjukkan komposisi agregat tipologi batas berdasarkan region dan kumulatif secara nasional.

Hasil tersebut menunjukkan di seluruh region terdapat subsegmen batas daerah yang tidak menggunakan unsur rupabumi sebagai penanda batasnya. Jika dikaitkan dengan status batas daerah (indikatif atau definitif), suatu batas yang tidak mengikuti unsur rupabumi tertentu pada segmen dengan status definitif bisa disebabkan karena batasnya telah disepakati mengikuti garis-garis lurus (tidak mengikuti unsur tertentu), atau terjadi kesalahan penggambaran oleh operator saat kegiatan penegasan batas daerah. Sedangkan jika kondisi tersebut terdapat pada batas daerah yang masih indikatif, kemungkinannya akan lebih banyak, seperti garis batas masih versi dari salah satu daerah karena belum ada proses verifikasi antardaerah, penggambaran batas masih menggunakan data yang belum detail sehingga menghasilkan garis yang tidak sesuai dengan unsur rupabumi, informasi terkait batas daerah yang tidak lengkap (misalnya peta dan dokumen kuno yang menjelaskan riwayat batas), atau terjadi kesalahan penggambaran oleh operator saat kegiatan pemetaan batas daerah. Tabel 1 menunjukkan perbandingan panjang subsegmen pada masing-masing tipologi batas yang dibedakan berdasarkan status batas daerah. Keseluruhan tipologi batas daerah didominasi oleh batas indikatif karena panjang segmen batas indikatif secara keseluruhan lebih dari 2 (dua) kali lipat dari panjang segmen batas definitif.

Setiap tipologi batas sangat dipengaruhi lokasi wilayah dan karakteristik lingkungannya. Gambar 8 memperlihatkan contoh batas wilayah yang disajikan diatas bentuk permukaan bumi pada sebagian wilayah di region Sumatera lebih tepatnya di sekitar Sumatera Utara dan Sumatera Barat. Wilayah yang memiliki karakteristik topografi berbukit memiliki tipologi batas daerah yang mengikuti unsur rupabumi lebih lengkap (jalan, sungai, dan igir). Namun, untuk area yang didominasi oleh dataran seperti batas antara Kabupaten Rokan Hilir dengan Kota Dumai hanya mengikuti unsur rupabumi berupa jalan dan sungai. Batas daerah di sekitar Danau Toba menjadi contoh lain bagaimana tipologi batas dipengaruhi karakteristik wilayah. Penentuan batas daerah di danau atau perairan daratan dapat menggunakan prinsip sama jarak yang diambil dari garis tepi perairan atau menggunakan garis tepi perairan itu sendiri. Jika menggunakan metode garis tengah, batas daerahnya akan berada diatas danau. Batas di tengah danau akan lebih mudah jika diidentifikasi dengan data penginderaan jauh (seperti foto udara, citra satelit, Digital Elevation Model (DEM)) dan SIG, meskipun masih memungkinkan dilacak di lapangan menggunakan teknologi Global Navigation Satellite System (GNSS) dengan mengacu pada nilai koordinat yang ada .

Pada penelitian ini, batas wilayah di danau dikategorikan ke dalam tipologi "tidak mengikuti unsur rupabumi" karena unsur perairan ini tidak digambarkan garis tengahnya.

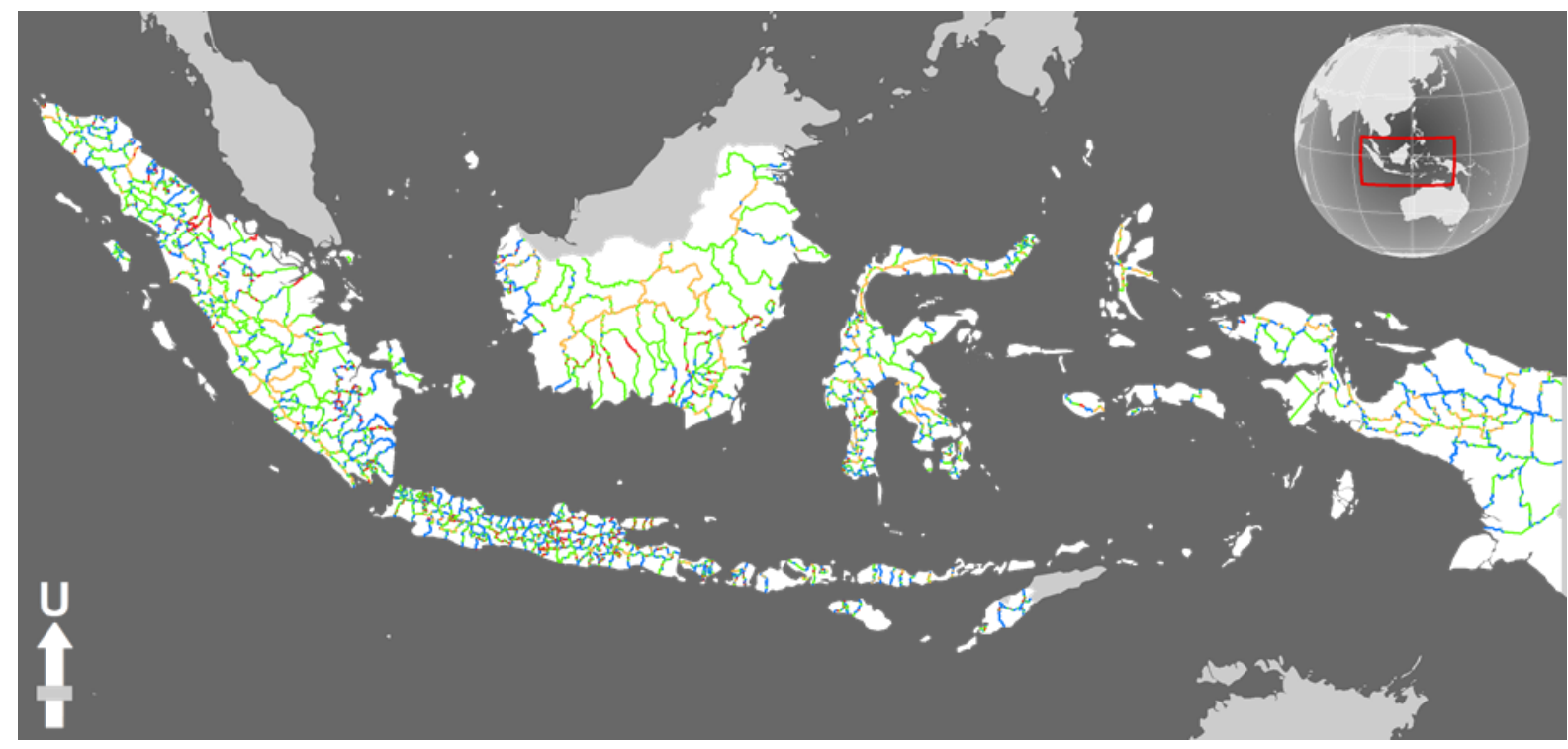

- Igir J Jalan - Sungai $\quad$ Tidak mengikuti unsur rupabumi

Gambar 6. Tipologi batas wilayah kabupaten/kota di Indonesia 


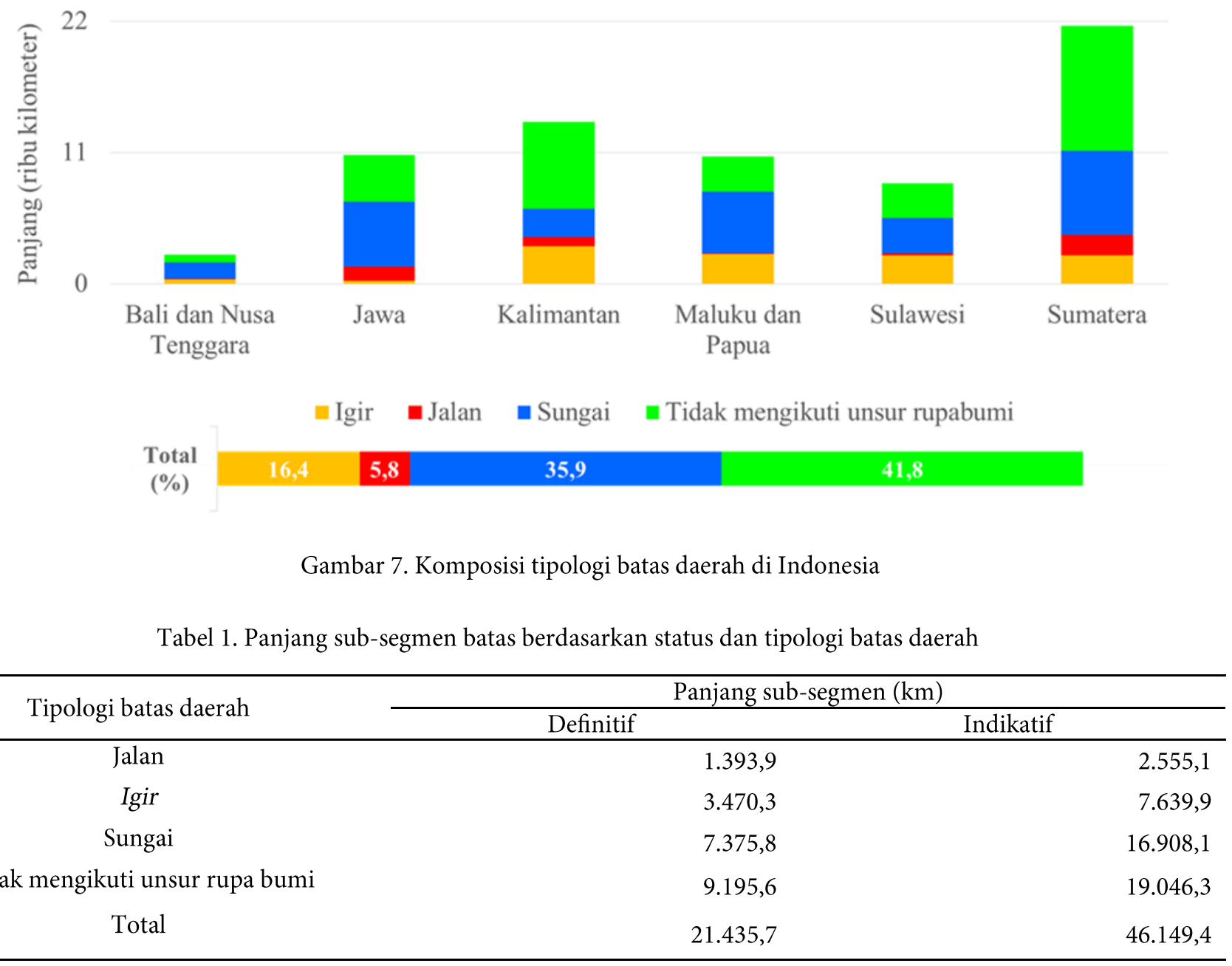

Berbeda dengan sungai yang mana selain garis tepi, juga digambarkan garis tengah bahkan thalweg (garis yang menghubungkan titik-titik terdalam sungai) sebagai representasi aliran yang merupakan prinsip utama sungai. Badan air yang bentuknya menyerupai pita tersebut mengalir ke tempat yang lebih rendah mengikuti gaya gravitasi atau dari hulu (pegunungan) ke hilir (muara) (Jacobs, n.d.; National Geographic Society, 2019). Tujuan aliran tersebut hampir sama dengan jalan yaitu untuk "memindahkan" dan representasinya harus berbentuk jaringan. Representasi sungai tergantung pada skala sumber data. Semakin besar skalanya maka representasi harus semakin lengkap dari mulai garis (polyline) untuk representasi garis tepi, thalweg, dan garis tengah, hingga area (poligon) untuk representasi badan air. Sebaliknya, semakin menurun skala, maka sungai yang berbentuk poligon memanjang biasanya memerlukan proses generalisasi dari garis ganda menjadi satu garis tengah sesuai ambang batas tertentu (Shen, Ai, Li, Huang, \& Li, 2020).

Wilayah perkotaan lebih berpeluang memiliki batas berupa unsur buatan manusia seperti jalan dan rel kereta. Salah satu karakteristik fisik perkotaan adalah adanya infrastruktur transportasi lebih banyak dibandingkan dengan perdesaan. Hal itu dibuktikan dengan kecenderungan kepadatan jaringan transportasi yang menurun dari pusat kota menuju pinggiran perkotaan dan distribusi jaringan transportasi di perkotaan lebih banyak dibandingkan di wilayah perdesaan (Lin et al., 2020). Perkotaan di Indonesia dapat dijumpai baik di wilayah kota maupun kabupaten. Hasil penelitian ini menunjukkan bahwa dari total segmen batas kabupaten/kota di 98 kota di Indonesia, panjang batas dengan tipologi jalan berada di urutan ketiga yaitu sekitar $14 \%$. Hal tersebut dapat disebabkan beberapa kemungkinan, misalnya letak kawasan perkotaan tidak selalu berbatasan dengan kota, melainkan berbatasan juga dengan kabupaten yang biasanya memiliki kepadatan jalan lebih rendah terlebih jika wilayah perbatasan kabupaten tersebut tidak mencirikan perkotaan.

Hasil penelitian ini memberikan informasi yang lengkap tentang kondisi tipologi batas daerah di Indonesia mulai dari persebaran (Gambar 6), komposisi (Gambar 7), kemungkinan faktor pembentuk, hingga status batas (Tabel 1) yang dapat dijadikan sebagai alat (untuk memudahkan) proses pengelolaan batas wilayah khususnya batas daerah provinsi dan kabupaten/kota di Indonesia sebagaimana menurut pendapat (Blake, 1998) tentang faktor pengelolaan batas wilayah. Contoh nyata pentingnya pengelolaan batas yang memperhatikan tipologi telah dibuktikan oleh (Donaldson, 2009; Earle, 2010; International Boundaries Research Unit (IBRU), n.d.; Popelka \& Smith, 2020; Toset et al., 2000) yaitu terkait pengelolaan sumber daya air (dalam hal ini sungai yang memiliki aliran antarnegara/lintas batas) dan hal tersebut sangat memerlukan informasi batas di sungai. Selain sungai, Indonesia memiliki sumber daya lain yang pengelolaannya melibatkan lebih dari satu wilayah administrasi yaitu jalan raya, jaringan pipa air bersih, jaringan listrik, sumber daya alam, dan lain sebagainya. Berdasarkan data Badan Pusat Statistik (BPS) tahun 2017, total panjang jalan di Indonesia selain jalan tol adalah $540.490 \mathrm{~km}$ yang terdiri atas $81 \%$ jalan kabupaten/kota, $10 \%$ jalan provinsi, dan $9 \%$ jalan negara. 
Pengelolaan batas memiliki interdependensi dengan pengelolaan objek fisik yang menjadi penanda batasnya. Interdependensi dalam hal ini berarti pengelolaan batas dipengaruhi kondisi pengelolaan objek fisik penanda batas yang ada pada saat ini dan sebaliknya. Misalnya, untuk melakukan pemasangan pilar batas yang menggunakan jalan sebagai penanda batasnya, diperlukan komunikasi dengan pengelola jalan karena berhubungan dengan ruang jalan tersebut. Jika tidak ada koordinasi dapat berimplikasi pada rusak bahkan hilangnya pilar batas karena tergusur pelebaran jalan. Padahal pemeliharaan pilar adalah salah satu upaya paling sederhana atau praktis dalam pengelolaan batas (Srebro \& Shoshany, 2013). Berikutnya, ilustrasi tentang pengelolaan objek fisik penanda batas yang dipengaruhi oleh pengelolaan batasnya yaitu pada beberapa subsegmen batas
Kota Palu dengan Kabupaten Sigi. Salah satu subsegmen Kota Palu dengan Kabupaten Sigi menggunakan tipologi jalan kabupaten/kota dan beberapa meter di antaranya saat ini telah hilang karena bencana likuefaksi. Proses rekonstruksi batas yang telah hilang tersebut akan mudah dilakukan oleh pemangku kepentingan jika tipologi batasnya telah tersedia dan didokumentasikan dengan baik mulai dari panjang, letak batas (di kanan, tengah, atau kiri jalan, dan koordinat). Pengelolaan jalan raya yang menjadi batas khususnya pada wilayah terdampak bencana akan tergantung pada hasil rekonstruksi batasnya. Berdasarkan seluruh uraian hasil analisis diatas, beberapa potensi manfaat tipologi batas wilayah administrasi disintesiskan menjadi beberapa hal kunci sebagaimana dapat dilihat pada Tabel 2.

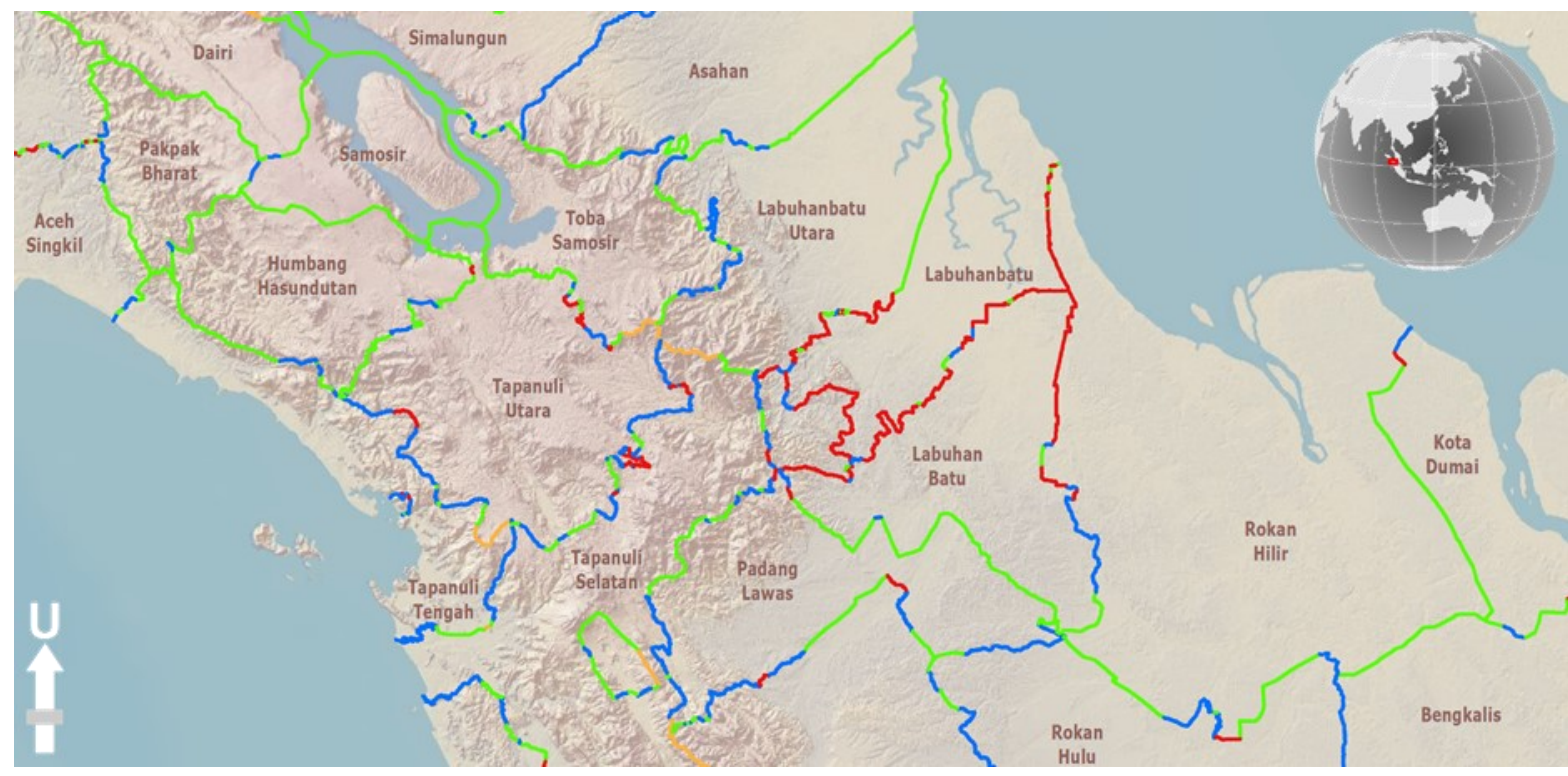

- Igir — Jalan - Sungai — Tidak mengikuti unsur rupabumi

Gambar 8. Contoh detail penanda batas pada sebagian wilayah di region Sumatera

Tabel 2. Sinteis manfaat tipologi untuk pengelolaan batas daerah

\begin{tabular}{ll}
\hline Potensi manfaat tipologi untuk pengelolaan batas daerah & Kegunaan sesuai status \\
\hline $\begin{array}{l}\text { Alat untuk identifikasi terhadap adanya potensi perbedaan antara penanda batas } \\
\text { di lapangan dengan data digital dan/atau untuk memperkirakan terjadinya } \\
\text { sengketa batas; }\end{array}$ & Indikatif dan definitif \\
\hline $\begin{array}{l}\text { Justifikasi alokasi sumber daya (waktu, manusia dan anggaran) ketika diperlukan } \\
\text { penelusuran batas di lapangan karena beban yang dibutuhkan sangat tergantung }\end{array}$ & \\
pada jarak dan medan penanda batasnya (misal menelusuri igir di pegunungan \\
lebih lama dan berat dibandingkan jalan di perkotaan);
\end{tabular}

\footnotetext{
Memudahkan pemeliharaan batas dalam jangka pendek maupun panjang (misalnya estimasi penambahan/perapatan dan/atau rekonstruksi pilar batas yang berpotensi hilang/rusak akibat pembangunan di sekitar batas atau terdampak bencana); dan
}

Definitif

Untuk dokumentasi historis jika di masa mendatang terdapat perubahan kondisi batas di lapangan (realita) karena faktor alamiah (misal bencana) maupun buatan (pembangunan). 


\section{KESIMPULAN}

Mayoritas wilayah Indonesia memiliki batas daerah yang tidak mengikuti unsur geografis sebagai pananda batasnya. $\mathrm{Hal}$ itu dapat disebabkan oleh beberapa kemungkinan yaitu: 1) batasnya telah disepakati mengikuti garis-garis lurus (tidak mengikuti unsur tertentu); 2) garis batas yang digambarkan adalah versi salah satu daerah karena belum ada proses verifikasi antardaerah; 3) penggambaran batas masih menggunakan data yang belum detail sehingga menghasilkan garis yang tidak sesuai dengan unsur rupabumi; 4) data atau informasi terkait batas daerah tidak lengkap (misalnya peta dan dokumen kuno yang menjelaskan riwayat batas); 5) atau terjadi kesalahan penggambaran oleh operator saat kegiatan pemetaan batas daerah. Namun demikian, untuk tipologi yang mengikuti unsur rupabumi sangat dipengaruhi lokasi wilayah dan karakteristik lingkungannya. Wilayah yang memiliki karakteristik topografi berbukit memiliki tipologi batas daerah yang mengikuti unsur rupabumi lebih lengkap (jalan, sungai, dan igir). Berbeda dengan di daerah dataran yang hanya menggunakan unsur rupabumi berupa jalan dan sungai sebagai penanda batas.

Hasil penelitian ini memberikan informasi yang lengkap tentang kondisi tipologi batas daerah di Indonesia mulai dari persebaran, komposisi, kemungkinan faktor pembentuk, hingga status batas. Beberapa sintesis terhadap potensi manfaat tipologi untuk pengelolaan batas daerah adalah: 1) alat evaluasi awal adanya potensi perbedaan antara penanda batas di lapangan dengan data digital dan/atau untuk memperkirakan terjadinya sengketa batas; 2) justifikasi alokasi sumber daya ketika diperlukan penelusuran batas di lapangan karena beban yang dibutuhkan sangat tergantung dengan jarak dan medan penanda batasnya; 3) memudahkan pemeliharaan batas dalam jangka pendek maupun panjang; dan 4) untuk dokumentasi historis jika di masa mendatang terdapat perubahan kondisi batas di lapangan karena faktor alamiah maupun buatan. Pada akhirnya, pengelolaan batas yang baik adalah ketika semua informasi tentang batas terdokumentasikan dengan baik sehingga dapat menjadi jembatan untuk mewujudkan keamanan nasional, kesejahteraan wilayah perbatasan, dan efektivitas pemerintah lokal.

Berikutnya, diperlukan penelitian lebih lanjut khususnya berkaitan dengan keterkaitan tipologi batas daerah dengan sengketa perbatasan. Sengketa perbatasan dalam hal ini dapat dikelaskan berdasarkan faktor yang memengaruhi misalnya ketersediaan sumber daya alam yang memicu sengketa. Penelitian tersebut diharapkan dapat memperkuat pentingnya tipologi batas dalam pengelolaan batas dan menjadi bagian untuk mewujudkan keamanan nasional, kesejahteraan wilayah perbatasan, dan efektivitas pemerintah lokal. Keamanan nasional dan perdamaian menjadi salah satu bagian Tujuan Pembangunan Berkelanjutan (TPB) sehingga penelitian tersebut akan bermanfaat bagi Indonesia pada khususnya dan global pada umumnya.

\section{UCAPAN TERIMA KASIH}

Penulis menyampaikan terima kasih kepada Pusat Pemetaan Batas Wilayah (Badan Informasi Geospasial) dan Direktorat Toponimi dan Batas Daerah (Kementerian Dalam Negeri) atas dukungan data utama yaitu segmen batas daerah kabupaten/kota di Indonesia. Selanjutnya, terima kasih juga disampaikan kepada Pusat Pemetaan Rupabumi dan
Toponimi dan Pusat Pengelolaan dan Penyebarluasan Informasi Geospasial (Badan Informasi Geospasial) yang telah memberikan akses terhadap data digital Peta Rupa Bumi Indonesia. Selain itu, ucapan terima kasih juga disampaikan kepada Dr. Sumaryo yaitu pakar yang telah memberikan pandangan keilmuan terkait pemetaan batas wilayah khususnya batas wilayah daerah (provinsi dan kabupaten/kota). Penulis mengucapkan terimakasih pada Pusat Penelitian, Promosi, dan Kerja Sama (Badan Informasi Geospasial) atas dukungan dana penelitian. Penelitian ini didanai oleh DIPA Badan Informasi Geospasial TA.2018 dan dipublikasikan melalui dana DIPA Badan Informasi Geospasial TA.2021.

\section{KONTRIBUSI PENULIS}

Kedudukan semua penulis adalah setara yaitu sebagai kontributor utama. FH menyusun konsep dan metode penelitian, visualisasi, dan menulis artikel. $\mathbf{M}$ melakukan analisis data, interpretasi hasil, dan menulis artikel. TRNR melakukan pengumpulan data, interpretasi hasil, dan penulisan artikel. Semua penulis melakukan proofread terhadap artikel yang telah disusun.

\section{DAFTAR PUSTAKA}

Adler, R. (2001). Boundary \& Territory Briefing: Geographical Information in Delimitation, Demarcation and Management of International Land Boundaries. (C. Schofield \& S. Furness, Eds.) (Volume $3 \mathrm{~N}$ ). Durham, UK: International Boundaries Research Unit, Durham University. Retrieved from https:// www.dur.ac.uk/ibru/publications/view/?id=219

Agrawal, A., \& Kumar, V. (2017). Cartographic conflicts within a union冈: Finding land for Nagaland in India. Political Geography, 61, 123-147. https://doi.org/10.1016/ j.polgeo.2017.06.015

Ahmad, A. G., \& Zuharnen, Z. (2017). Pemanfaatan Citra Penginderaan Jauh dan Metode Kartometris untuk Analisis Perubahan Batas Desa Studi Kasus: Desa Baturetno, Kecamatan Banguntapan, Kabupaten Bantul. Jurnal Bumi Indonesia, 6(3).

Anderson, D. L., Ames, D. P., \& Yang, P. (2014). Quantitative Methods for Comparing Different Polyline Stream Network Models. Journal of Geographic Information System, 06(02), 8898. https://doi.org/10.4236/jgis.2014.62010

Anggoro, P. (2018). Penentuan Batas Wilayah Menggunakan Metode Kartometrik. ITN MALANG.

Arifin, S. (2016). Penyelesaian Sengketa Batas Daerah Menggunakan Pendekatan Regulasi. Jurnal Hukum Ius Quia Iustum, 23(3), 439-460. https://doi.org/10.20885/ iustum.vol23.iss3.art5

Ariza-López, F. J., Ruiz-Lendínez, J. J., \& Ureña-Cámara, M. A. (2018). Influence of Sample Size on Automatic Positional Accuracy Assessment Methods for Urban Areas. International Journal of Geo-Information, 7, 200. https://doi.org/10.3390/ ijgi7060200

Asadi. (2016). Penataan Batas wilayah Administrasi Desa, Hambatan dan Alternatif Solusi dengan Pendekatan Geospasial. Jurnal Borneo Administrator, 12(2).

Astuty, Y. I., Hidayat, F., \& Prihanggo, M. (2019). Hubungan Skala Batas Antar Kabupaten/Kota dengan Batas Antar Desa/ Kelurahan dalam Konteks Penegasan Batas Wilayah (Studi Kasus di Kabupaten Rembang dan Kabupaten Blora). In Seminar Nasional Geomatika 2018 (Vol. 3, pp. 835-840).

Badan Informasi Geospasial. Peraturan Kepala Badan Informasi Geospasial Nomor 15 Tahun 2014 tentang Pedoman Teknis Ketelitian Peta Dasar (2014). Indonesia.

Bashit, N., Prasetyo, Y., Firdaus, H. S., \& Amarrohman, F. J. (2019). Penetapan Batas Desa Secara Kartometrik Menggunakan Citra Quickbird. Jurnal Pasopati, 1(76), 9-15. 
Blake, G. H. (1998). The Objectives of Land Boundary Management. IBRU Boundary and Security Bulletin, 6(3), 55-59. Retrieved from https://www.dur.ac.uk/ibru/publications/view/?id=137

Caflisch, L. (2010). A Typology of Borders. In B. Vukas \& Trpimir (Eds.), International Law: New Actors, New Concept-Continuing Dilemmas (pp. 183-220). Brill.

Donaldson, J. W. (2009). Where rivers and boundaries meet: building the international river boundaries database. Water Policy, 11(5), 629-644. https://doi.org/10.2166/wp.2009.065

Dumanauw, T. (2013). Penyelesaian Sengketa Tapal Batas Antara Kabupaten Minahasa Utara dan Kota Bitung. Lex Administratum, 1(1).

Earle, A. (2010). Transboundary Water Management: Principles and Practice. (A. Jägerskog \& J. Öjendal, Eds.). Routledge.

ESRI. (2019). Quick Notes on Map Projections in ArcGIS.

Femenia-Ribera, C., Benitez-Aguado, E., Mora-Navarro, G., \& Martinez-Llario, J. (2014). Method of recovering municipal boundary lines in Province of Valencia (Spain) by means of historical cadastral maps. Survey Review, 46(337), 255-266.

Goodchild, M. F., \& Hunter, G. J. (1997). A simple positional accuracy measure for linear features. International Journal of Geographical Information Science, 11(3), 229-306. https:// doi.org/10.1080/136588197242419

Harvey, F. (2006). Reconfiguring Administrative Geographies In The United States. ACME: An International E-Journal for Critical Geographies, 4(1), 57-79.

Hidayat, F., Astuty, Y. I., Suryanto, \& Saputro, G. B. (2015). Karakteristik Batas WIilayah Administrasi Daerah di Indonesia berdasarkan Tipologi Batas Wilayah. In P. Wicaksono, M. Kamal, S. Lestari, I. Wicaksono, D. Setiady, \& A. B. Arundina (Eds.), Simposium Nasional Sains Geoinformasi IV 2015: Penguatan Peran Sains Informasi Geografi dalam Mendukung Penanganan Isyu-isyu Strategis Nasional (pp. 581-590). Yogyakarta: PUSPICS Fakultas Geografi UGM.

Hidayat, F., Riadi, B., \& Turmudi. (2018). Perkembangan Penegasan Batas Kabupaten/Kota di Era Otonomi Daerah. In Prosiding Simposium Infrastruktur Informasi Geospasial (SIIG 2018): Infrastruktur Informasi Geospasial untuk Mendukung Kebijakan Satu Peta (pp. 49-53). Yogyakarta: Departemen Teknik Geodesi FT UGM.

International Boundaries Research Unit (IBRU). (n.d.). International River Boundaries Database. Retrieved from https://www.dur.ac.uk/ibru/resources/irbd/

Jacobs, J. W. (n.d.). Rivers, Major World. Retrieved from http:// www.waterencyclopedia.com/Re-St/Rivers-Major-World.html

Jones, C. B. (1945). Boundary Making: A Handbook for Statesmen, Treaty Editors and Boundary Commissioners. Washington D.C.: Carnegie Endowment for International Peace.

Khomsin, Widiastuty, R., Alif, T. F., \& Artanto, E. (2015). A Determination Analysis of Regional Maritime Boundary Based on Regulation of Home Ministry Affair Number 76 in 2012 (Case Study: Dispute of Galang Island Border between Surabaya and Gresik). Procedia Earth and Planetary Science, 14, 83-93. https://doi.org/10.1016/j.proeps.2015.07.088

Kristiyono, N. (2008). Konflik dalam Penegasan Batas Daerah antara Kota Magelang dengan Kabupaten Magelang (Analisis Terhadap Faktor-faktor Penyebab dan Dampaknya). program Pascasarjana Universitas Diponegoro.

La Suhu, B., Noor, N., \& Djae, R. M. (2018). Batas Daerah dalam Pusaran Konflik di Provinsi Maluku Utara (Studi Tentang Penyelesaian Sengketa Tapal Batas Antara Kabupaten Halmahera Timur Dan Kabupaten Halmahera Tengah). Ejournal KAWASA, 8(4), 1-11.

Lin, Y., Hu, X., Lin, M., Qiu, R., Lin, J., \& Li, B. (2020). Spatial Paradigms in Road Networks and Their Delimitation of Urban Boundaries Based on KDE. ISPRS International Journal of GeoInformation, 9(4). https://doi.org/10.3390/ijgi9040204

National Geographic Society. (2019). River. Retrieved November 3, 2020, from https://www.nationalgeographic.org/encyclopedia/ river/
Popelka, S. J., \& Smith, L. C. (2020). Rivers as political borders: a new subnational geospatial dataset. Water Policy, 22, 293-312. https://doi.org/10.2166/wp.2020.041

Prakasa, S. (2017). Validasi Batas Administrasi Desa Menggunakan Metode Kartometrik (Studi Kasus: Kecamatan Lumajang, Kabupaten Lumajang). Institut Teknologi Sepuluh Nopember.

Pratiwi, I. D. (2018). Kajian Delineasi Batas Desa di Kabupaten Kulon Progo Provinsi Daerah Istimewa Yogyakarta. Universitas Gadjah Mada.

Prescott, J. R. V. (1965). The Geography of Frontiers and Boundaries. New York: Rutledge.

Prihandito, A. (2014). Proyeksi Peta (5th ed.). Yogyakarta: Penerbit Kanisius.

Putra, I. W. K. E., \& Dewi, G. A. K. R. S. (2020). Pemetaan Partisipatif Batas Wilayah Desa Tangguwisia dan Desa Kalianget Kecamatan Seririt-Buleleng. Proceeding Senadimas Undiksha, 1556.

Riadi, B., \& Makmuriyanto, A. (2014). Kajian Percepatan Penetapan dan Penegasan Batas Kecamatan/Distrik, Desa/Kelurahan Secara Kartometris. Majalah Ilmiah Globe, 16(2).

Riadi, B., \& Soleman, M. K. (2011). Aspek Geospasial Dalam Delineasi Batas Wilayah Kota Gorontalo. Majalah Ilmiah Globe, 13(1).

Ruiz-lendínez, J. J. (2020). Abandoned Farmland Location in Areas Affected by Rapid Urbanization Using Textural Characterization of High Resolution Aerial Imagery. International Journal of Geo-Information, 9, 191. https:// doi.org/10.3390/ijgi9040191

Ruiz-Lendínez, J. J., Ariza-López, F. J., \& Ureña-Cámara, M. A. (2013). Automatic positional accuracy assessment of geospatial databases using line-based methods. Survey Review, 45, 332342. https://doi.org/10.1179/1752270613Y.0000000044

Rumesten, I. (2013). Strategi Hukum dan Penerapan Partisipasi Masyarakat dalam Penyelesaian Sengketa Batas Daerah di Sumatera Selatan. Jurnal Hukum Ius Quia Iustum, 20(4), 602623.

Sardiana, I. K., \& Windia, I. W. P. (2018). Pemetaan Partisipatif melalui Aplikasi GPS untuk Mitigasi Kon ik Batas Wilayah: Studi Kasus di Desa Adat Nyuh Kuning, Ubud, Bali. Jurnal Kajian Bali (Journal of Bali Studies), 8(1), 145-158.

Shen, Y., Ai, T., Li, J., Huang, L., \& Li, W. (2020). A progressive method for the collapse of river representation considering geographical characteristics. International Journal of Digital Earth, $\quad 0(0), \quad 1-25 . \quad$ https:// doi.org/10.1080/17538947.2020.1715495

Sinaga, M. I. (2015). Evaluasi Perbandingan Ketelitian Hasil Deliniasi Batas Desa Secara Kartometrik. Universitas Gadjah Mada.

Srebro, H., \& Shoshany, M. (2013). The Process of International Boundary Making. In H. Srebro (Ed.), International Boundary Making (FIG Public, pp. 17-40). Copenhagen, Denmark: International Federation of Surveyors (FIG).

Sumaryo. (2015). Asesmen Peran Informasi Geospasial dalam Proses Boundary Making dan Sengketa Batas Daerah Pada Era Otonomi Daerah di Indonesia. Universitas Gadjah Mada.

Sumaryo, S., Sutisna, S., Subaryono, S., \& Djurdjani, D. (2014). Penaksiran Informasi Geospasial, Aspek Datum Geodesi dalam Penetapan dan Penegasan Batas Daerah Pada Era Otonomi Daerah di Indonesia. GEOMATIKA, 20(1).

Sumaryo, Subaryono, S., \& Sutisna, S. (2014). Geospatial Information and Regional Boundary Dispute in the Regional Boundary Demarcation during the Regional Autonomy Era in Indonesia Geospatial Information and Regional Boundary Dispute in the Regional Boundary Demarcation during the Regional Autonomy. In FIG Congress 2014: Engaging the Challenges - Enhancing the Relevance. Kuala Lumpur.

Sumaryo, Subaryono, Sutisna, S., \& Wardaya, D. (2014). Geospatial Information and Regional Boundary Dispute in the Regional Boundary Demarcation during the Regional Autonomy Era in Indonesia. In FIG Congress 2014 Engaging the Challenges - 
Enhancing the Relevance. Kuala Lumpur.

Sutanta, H., Pratiwi, I. D., Atunggal, D., Cahyono, B. K., \& Diyono, D. (2020). Analisis Hasil Penetapan Batas Desa di Kabupaten Gunungkidul Provinsi Daerah Istimewa Yogyakarta. GEOMATIKA, 26(2), 83-94.

Talitha, S. (2015). Penetapan Dan Penegasan Batas Desa Di Kabupaten Sidoarjo Berdasarkan Permendagri No. 27 Tahun 2006. Universitas Brawijaya.

Toset, H. P. W., Gleditsch, N. P., \& Hegre, H. (2000). Shared Rivers and Interstate Conflict. Political Geography, 19(8), 971-996. Retrieved from https://www.prio.org/Data/\%0AGeographicaland-Resource-\%0ADatasets/Shared-Rivers/

Vallo, D., Valovicova, L., \& Kramarekova, H. (2019). Mercator Projection as a Tool for Development of Interdisciplinary Relations Among Physics, Mathematics and Geography. In L. Valovicova, J. Ondruska, \& L. Zelenicky (Eds.), AIP Conference Proceedings (Vol. 2152, pp. 030034-1-030034-9). Terchova, Slovakia. https://doi.org/https://doi.org/10.1063/1.5124778

Wibowo, T. W., Ambhika, N., \& Pratama, A. P. (2019). Teknik Geovisualisasi untuk Percepatan Pemetaan Batas Desa di Daerah Berbukit. MAJALAH ILMIAH GLOBE, 21(1), 35-44.

Zarodi, H., Rofi, A., Anshori, M., \& Widarto, M. (2019). Pemanfaatan Teknologi GIS \& Penginderaan Jauh untuk Membuat Peta Batas Dusun Partisipatif di Desa Sumber, Kecamatan Dukun, Kabupaten Magelang. 